\title{
Richtlijn stotteren 2020: Wat er is veranderd en waarom
}

\author{
Leonoor C. Oonk ${ }^{1}$, Anneke G.M. Busser ${ }^{2}$ \\ ${ }^{1}$ Voorzitter werkgroep Herziening richtlijn stotteren \\ ${ }^{2}$ Schrijvend lid werkgroep Herziening richtlijn stotteren
}

\begin{abstract}
Samenvatting
De evidence-based richtlijn stotteren geeft antwoord op een aantal uitgangsvragen over onderzoek, behandeling, verwijzing en nazorg bij personen die stotteren. In 2020 is de richtlijn uit 2014 herzien. Het startpunt was om geen nieuwe uitgangsvragen te formuleren maar om de bestaande vragen te actualiseren. De werkgroep die de richtlijnherziening heeft uitgevoerd bestond uit vertegenwoordigers van de Nederlandse Vereniging voor Logopedie en Foniatrie (NVLF), de Nederlandse Vereniging voor Stottertherapie (NVST) en de patiëntenvereniging de Nederlandse Stottervereniging Demosthenes (Demosthenes).

Relevante nieuwe publicaties werden geëvalueerd en gewaardeerd op kwaliteit van bewijs. De gebruikers van de richtlijn is gevraagd om commentaar te geven op de oude richtlijn. Dit commentaar is meegenomen in de overwegingen.

In dit artikel worden de wijzigingen in de aanbevelingen per uitgangsvraag toegelicht en onderbouwd. Daarbij wordt ook aangegeven welk nader onderzoek gewenst is om lacunes op te vullen in de kennis over de diagnostiek en behandeling van stotteren.
\end{abstract}

\section{Summary}

The Dutch Evidence-based Clinical Guideline Stuttering provides answers to a number of key questions about assessment, treatment, referral and aftercare of people who stutter. The 2014 guideline was revised in 2020 . The starting point of this revision was not to formulate new key questions, but to update existing ones. The working group responsible for this revision consisted of representatives of the Dutch Association for Speech Therapy and Phoniatrics (NVLF), the Dutch Association for Stuttering Therapy (NVST) and the patient association Dutch Stuttering Association Demosthenes (Demosthenes).

Relevant new publications were evaluated and rated for quality of evidence. The guideline users were asked to comment on the former 2014 guideline. These comments were taken into account.

This paper explains the changes in the recommendations for each key question with examples of the supporting evidence. Recommendations are given for future research on diagnostics and treatment of stuttering.

Correspondentieadres:

Leonoor Oonk, MSc

Voorzitter werkgroep Herziening richtlijn stotteren

E-mail: leonoor.oonk@gmail.com
Dit artikel is gelicentieerd onder de Creative Commons CC BY-NC-ND 4.0 (NaamsvermeldingNietCommercieel-GeenAfgeleideWerken) Internationale Licentie. Gebruik en distributie voor commerciële doeleinden en elke distributie van aangepast materiaal vereist schriftelijke toestemming. 


\section{Inleiding}

De richtlijn stotteren bij kinderen, adolescenten en volwassenen is in 2014 geïntroduceerd als eerste Nederlandse monodisciplinaire richtlijn voor logopedisten (Pertijs e.a. 2014). Het initiatief voor het ontwikkelen van deze evidence-based richtlijn was genomen door de $\mathrm{Ne}$ derlandse Vereniging voor Stotterňtherapie (NVST), de Nederlandse Vereniging voor Logopedie en Foniatrie (NVLF) de Nederlandse Stottervereniging Demosthenes (Demosthenes), de patiëntenvereniging voor (ouders van) kinderen en volwassen die stotteren. De richtlijn is ontwikkeld onder auspiciën van de NVLF; de NVLF is de opdrachtgever en eigenaar van de richtlijn.

Met stotteren wordt in de richtlijn het ontwikkelingsstotteren bedoeld, dat ontstaat in de kindertijd en wordt onderscheiden van stotteren dat ontstaat door neurologisch letsel, door een psychische stoornis of door andere somatische aandoeningen (DSM-5, 2016).

Het formuleren van aanbevelingen voor het logopedisch handelen bij stotteren is vooral van belang op punten waar de zorg niet goed loopt. Daarom werd er in 2014 begonnen met het inventariseren van knelpunten in de logopedische zorg rond stotteren. Personen die stotteren en betrokken zorgprofessionals werden uitgenodigd om een knelpuntenquête in te vullen. De knelpunten werden nader uitgediept tijdens een focusgroepbijeenkomst met personen die stotteren en ouders van kinderen die stotteren. Er bleek behoefte te bestaan aan meer duidelijkheid over het moment waarop diagnostiek dient plaats te vinden, over de inhoud van de diagnostiek, de inhoud en timing van de behandelingen en wanneer en naar wie een persoon die stottert moet worden doorverwezen. Op basis hiervan werden er acht uitgangsvragen geformuleerd die in de richtlijn zijn beantwoord en waaruit vervolgens 25 aanbevelingen voor het logopedisch handelen zijn geformuleerd (Oonk \& Pertijs, 2014).

In 2019 heeft de NVLF onderzocht of herziening wenselijk is. Richtlijnen zijn immers geen statische instrumenten, maar bewegen mee met nieuwe kennis en inzichten. Redenen om tot herziening over te gaan waren nieuwe wetenschappelijke publicaties, waaronder Nederlands onderzoek en het verschijnen van een Duitse richtlijn voor stotteren (Neumann e.a., 2016). De richtlijn uit 2014 is een lijvig document met veel tekst en de leesbaarheid is niet altijd optimaal (zie verder inventarisatie gebruik richtlijn in dit artikel). Een herziening zou een compactere, voor logopedisten beter leesbare richtlijn moeten opleveren met aanbevelingen die helderder geformuleerd zijn. Startpunt bij de herziening was om geen nieuwe uitgangsvragen te formuleren maar om de bestaande vragen te verhelderen en te actualiseren.

\section{Werkwijze}

\section{Wetenschappelijke onderbouwing}

Er werd een literatuurzoektocht gehouden in de relevante databases over de periode 20132019. Daarbij werden dezelfde zoekstrategieën gebruikt als bij de ontwikkeling van de richtlijn in 2013-2014. Artikelen werden gezocht door het verrichten van systematische zoek- 
acties in relevante databaseste weten de Cochrane Library, Medline, Embase, Psycinfo en Cinahl. Bij elke uitgangsvraag hoort een aparte zoekstrategie, deze is kort beschreven per uitgangsvraag. De zoekstrategie voor de revisie is in twee tranches uitgevoerd: 1) een wat gebruikte bronnen en zoektermen betreft uitgebreide search naar richtlijnen en systematische reviews/meta-analysen en 2) een specifieke search naar primaire studies in Medline/PubMed. Een overzicht van de zoekacties voor de eerste richtlijn (2014) en de revisie (2019) is te vinden in de Appendix bij de herziene richtlijn 2020 (NVLF, 2020).

Voor de resultaten van de zoekacties zijn de volgende selectiecriteria gehanteerd:

- voor therapie: uitsluitend fase II- en III-trials ${ }^{1}$ plus andere studies met een direct vergelijkende opzet, in alle gevallen met minimaal 50 personen (25 per groep)

- voor diagnostiek/screening: minimaal $\mathrm{n}=50$ personen

- voor kwalitatief onderzoek (ervaringen van personen die stotteren, ervaringen van therapeuten): minimaal $\mathrm{n}=25$ personen

Voor het formuleren van een aanbeveling zijn er naast het wetenschappelijk bewijs ook andere aspecten van belang, bijvoorbeeld: de balans van gewenste en ongewenste effecten, de belasting van een therapie, cliëntvoorkeuren, professioneel perspectief, maatschappelijke consequenties of kosten. In het kader van het professionele perspectief zijn relevante therapievormen en behandelprogramma's die niet voldeden aan de inclusiecriteria en derhalve niet zijn meegenomen in de wetenschappelijke onderbouwing, toch besproken.

Na selectie van de relevante literatuur werden de artikelen gericht op therapeutische interventies door een richtlijnen methodoloog beoordeeld op kwaliteit met behulp van drie verschillende evaluatie-instrumenten. De kwaliteit van vergelijkbare, internationale richtlijnen (in dit geval de Duitse richtlijn over stotteren die als enige richtlijn gepubliceerd na 2014 uit de literatuursearch naar boven kwam), werd beoordeeld met behulp van de Appraisal of International Guidelines, Research and Evaluation (AGREE II)-checklist (agreetrust.org). De AGREE -II checklist beoordeelt zes verschillende domeinen van richtlijnontwikkeling op een zeven-puntsschaal: onderwerp en doel, betrokkenheid van belanghebbenden, methodologie, helderheid en presentatie, toepassing en onafhankelijkheid van de opstellers.

De kwaliteit van de gevonden systematische reviews werd beoordeeld met AMSTAR 2 (A MeaSurement Tool to Assess systematic Reviews) (Shea e.a., 2017). Dit instrument omvat zestien vragen waarmee de methodologische achtergrond van de review kritisch wordt geëvalueerd.

De kwaliteit van bewijs van individuele studies werd beoordeeld met behulp van GRADE (Guyatt 2008, Hultcrantz 2017). GRADE is een methode die per uitkomstmaat van een interventie een gradering aan de kwaliteit van bewijs toekent op basis van de mate van vertrou-

\footnotetext{
${ }^{1}$ Fase II-trial: de werkzaamheid van de interventie wordt onderzocht bij een groep participanten om een indicatie te krijgen of deze effectief is.

Fase III-trial: de werkzaamheid van de interventie wordt op grotere schaal getest en de significantie van de uitkomsten wordt berekend.
} 
wen in de schatting van de effectgrootte.

Bij methoden die in het verleden werden gebruikt was het studiedesign doorslaggevend voor de kwaliteit van bewijs. Daarbij werd ervan uitgegaan dat een randomised controlled trial (RCT) automatisch een garantie was voor een hoge kwaliteit van bewijs. GRADE daarentegen beoordeelt een studie op onderzoeksdesign, aantal proefpersonen, inconsistentie, indirectheid, onnauwkeurigheid, het risico op bias per uitkomstmaat en op effectgrootte. Een matig uitgevoerde RCT, waarbij wel een effect wordt aangetoond, kan met GRADE toch worden afgewaardeerd op grond van de kwaliteit van de studie. Hierdoor kan uiteindelijk de kwaliteit van het bewijs alsnog laag beoordeeld worden. De kwaliteit van het bewijs doet een uitspraak over de mate van zekerheid over de aangetoonde effectgrootte per uitkomstmaat. Een hoge kwaliteit betekent dat er een redelijk groot vertrouwen is dat het werkelijke effect van de interventie voor de hele populatie dicht in de buurt ligt van het effect dat is gevonden in de onderzoeksgroep. Bij een lage kwaliteit is dat vertrouwen gering.

De beoordelingen met AGREE-II, AMSTAR en GRADE zijn terug te vinden in de appendix van de herziene richtlijn (NVLF, 2020).

\section{Inventarisatie gebruik richtlijn}

Om knelpunten bij het gebruik van de richtlijn uit 2014 te inventariseren, werd een enquête uitgezet onder de leden van de NVLF en de NVST. Daarnaast is Demosthenes om input gevraagd. De enquête bevroeg de duidelijkheid van de aanbevelingen en de toepasbaarheid in de praktijk. De respondenten werden daarnaast uitgenodigd om open commentaar te leveren op de aanbevelingen. 58 logopedisten en stottertherapeuten vulden de enquête volledig in. Daarbij werd veel gebruik gemaakt van de mogelijkheid om commentaar te geven (281 opmerkingen) ${ }^{2}$. Op basis van de resultaten is gekeken welke aanbevelingen in de praktijk voor onduidelijkheid zorgen; opmerkingen over de uitvoerbaarheid van de aanbevelingen en de overige opmerkingen werden gebruikt als input voor de herziening.

Verder is onderzocht of op basis van de cijfers van Vektis (een organisatie die operationele processen tussen ziektekostenverzekeraars, zorgverleners en overheden faciliteert, vektis.nl) trends te zien zijn binnen logopedische zorg voor personen die stotteren, specifiek of er ten opzichte van 2014 (het jaar dat de richtlijn is vastgesteld) veranderingen te zien zijn in het declaratiegedrag van logopedisten en logopedist-stottertherapeuten. Zijn logopedisten bijvoorbeeld eerder gaan doorverwijzen naar de logopedist-stottertherapeut? Uit de beschikbare database bleek deze vraag niet te beantwoorden omdat een verwijzing van logopedist naar stottertherapeut niet is geregistreerd. Het gemiddelde aantal behandelingen per stotterende cliënt lijkt vanaf 2015 wel iets af te nemen (zie Tabel 1), maar of dit een gevolg is van de aanbeveling uit de richtlijn om regelmatiger te evalueren en te verwijzen bij onvoldoende resultaat, is onmogelijk hard te maken.

\footnotetext{
${ }^{2}$ Resultaten zijn opvraagbaar bij de eerste auteur
} 
Tabel 1: Data afkomsting van Vektis: verrichtingen stottertherapie van 2011 tot 2017

\begin{tabular}{llll}
\hline $\begin{array}{l}\text { Declaratie 4301 indivi- } \\
\text { duele zitting logopedie }\end{array}$ & $\begin{array}{l}\text { aantal } \\
\text { declaraties }\end{array}$ & $\begin{array}{l}\text { aantal } \\
\text { patiënten }\end{array}$ & $\begin{array}{l}\text { gemiddeld aantal be- } \\
\text { handelingen per patiënt }\end{array}$ \\
\hline 2011 & 3.386 .220 & 205.260 & 16,5 \\
2012 & 3.561 .734 & 211.285 & 16,9 \\
2013 & 3.480 .460 & 208.768 & 16,7 \\
2014 & 3.359 .829 & 206.125 & 16,3 \\
2015 & 3.392 .528 & 213.086 & 15,9 \\
2016 & 3.560 .868 & 222.317 & 16,0 \\
2017 & 3.628 .303 & 229.507 & 15,8 \\
\hline
\end{tabular}

\section{Samenstelling en werkwijze werkgroep}

De werkgroep die de herziening van de richtlijn heeft uitgevoerd bestond uit vertegenwoordigers van de NVLF, de NVST en Demosthenes. De werkgroepleden handelden onafhankelijk en waren gemandateerd door hun vereniging voor deelname aan de werkgroep.

De werkgroep heeft gedurende een periode van ongeveer zeven maanden gewerkt aan het actualiseren van de antwoorden op de uitgangsvragen en het opstellen van de tekst voor de herziene richtlijn. De conclusies uit de literatuur vormden de basis voor het opstellen van de aanbevelingen. De uitkomsten uit de enquête onder logopedisten zijn hierbij meegewogen. De aanbevelingen zijn tot stand gekomen op basis van consensus binnen de werkgroep. Voor een beperkt aantal uitgangsvragen (uitgangsvraag zes en zeven) hebben werkgroepleden een tekst geschreven die niet is gebaseerd op de resultaten van systematisch literatuuronderzoek, omdat hiervoor niet of nauwelijks wetenschappelijk bewijs aanwezig was. Tijdens plenaire vergaderingen zijn alle teksten besproken en geaccordeerd na verwerking van het commentaar (consensus aanbevelingen). De door de werkgroep geaccordeerde conceptrichtlijn is vervolgens voor commentaar aangeboden aan de leden van een klankbordgroep, de besturen van de NVLF, Demosthenes en de NVST en alle leden van de NVLF en de NVST. De klankbordgroep bestond uit beroepsorganisaties die betrokken zijn bij de diagnostiek en behandeling van stotteren. De beroepsorganisaties die bij de oude richtlijn uit 2014 deel uitmaakten van de klankbordgroep hebben opnieuw input geleverd voor de herziene richtlijn.

Na de verwerking van dit commentaar is een definitief concept van de herziene richtlijn door de werkgroep vastgesteld en ter autorisatie aan het bestuur van de NVLF, de opdrachtgever van deze herziening, aangeboden. De herziene richtlijn is 29 juni 2020 vastgesteld en vervolgens gepubliceerd. Tabel 3 (Appendix) toont een overzicht van alle aanbevelingen in de herziene richtlijn. 


\section{Overzicht wijzigingen met onderbouwing}

\section{Uitgangsvragen}

In deze paragraaf wordt per uitgangsvraag een toelichting met een korte onderbouwing gegeven op een aantal wijzigingen; voor een overzicht van de uitgangsvragen zie Tabel 2. Om aan te geven waar er nog kennis ontbreekt, wordt aan het einde van bespreking van iedere uitgangsvraag aanbevelingen gedaan voor verder onderzoek.

Zoals omschreven in de inleiding werden er geen nieuwe uitgangsvragen geformuleerd; wel werden een aantal uitgangsvragen wat formulering betreft aanscherpt. Zo werd bij de afgrenzing van de leeftijdsgroepen naast de kalenderleeftijd ook de basisschoolgroep van het kind meegenomen in de definitie zodat de aanbevelingen beter aansluiten bij de ontwikkeling van het kind, waarbij de basisschoolgroep prevaleert boven de kalenderleeftijd. De uitgangsvraag: "Wat zijn de effecten van farmacotherapie bij kinderen, adolescenten en volwassenen die stotteren?", uit de richtlijn van 2014 is vervallen en bij de herziening niet als aparte vraag in een hoofdstuk opgenomen maar in het kader van een logische opbouw van de tekst, meegenomen bij de uitgangsvragen vier en vijf over de effecten van therapie.

Tabel 2: Herziene uitgangsvragen.

1. Wat zijn de indicaties om kinderen, adolescenten en volwassenen die stotteren te behandelen?

2. Wat is de diagnostische waarde van tests bij kinderen, adolescenten en volwassenen die stotteren?

3. Wat zijn de effecten van stottertherapieën bij kinderen tot en met zes jaar die stotteren? (tot en met groep twee van de basisschool)

4. Wat zijn de effecten van stottertherapieën bij kinderen van zes tot dertien jaar die stotteren? (groep drie tot en met groep acht van de basisschool)

5. Wat zijn de effecten van stottertherapieën bij adolescenten en volwassenen die stotteren?

6. Hoe dient adequate nazorg te worden georganiseerd en uitgevoerd bij kinderen, adolescenten en volwassenen die stotteren?

7. Wanneer en met welke reden dienen kinderen, adolescenten en volwassenen die stotteren te worden doorverwezen?

Noot: De uitgangsvraag: 'Wat zijn de effecten van farmacotherapie in het kader van stottertherapie bij kinderen, adolescenten en volwassenen die stotteren?' werd bij de herziening beantwoord bij de uitgangsvragen vier en vijf. 


\section{Uitgangsvraag 1: Wat zijn de indicaties om kinderen, adolescenten en vol- wassenen die stotteren te behandelen?}

\section{Monitoring}

In de richtlijn van 2014 waren er acht aanbevelingen bij uitgangsvraag 1 waarbij zeven van de acht aanbevelingen betrekking hadden op de indicaties om kinderen tot en met zes jaar te behandelen. Dit heeft te maken met het mogelijke natuurlijk herstel van stotteren in deze leeftijdsgroep: het herstel van stotteren zonder dat behandeling plaatsvindt. De logopedist zal zich afvragen wanneer het natuurlijk herstel nog kan worden afgewacht en wanneer het belangrijk is de behandeling te starten. Monitoring werd aanbevolen als een manier om gecontroleerd het natuurlijk herstel te volgen zonder dat behandeling plaats heeft gevonden.

Uit de enquête over de richtlijn van 2014 bleek dat de formulering van de aanbevelingen die betrekking hebben op kinderen tot en met zes jaar verwarring kan geven. De onduidelijkheid betrof met name de manier waarop de leeftijden, genoemd in de verschillende aanbevelingen, met elkaar in samenhang dienen te worden gewogen. Ook kwam naar voren dat het proces van monitoren voor de praktijk onvoldoende is beschreven.

In de herziening is in aanbeveling 1 de precieze leeftijd (vóór de leeftijd van 4;6 jaar) en de tijd sinds het ontstaan van stotteren (minder dan een half jaar) als voorwaarde om te gaan monitoren, afgegrensd. Er is toegevoegd dat monitoren kan worden voortgezet zolang het herstel zich voortzet. In de herziene richtlijn is een uitgebreide handreiking toegevoegd hoe monitoring uitgevoerd kan worden. Hierbij wordt duidelijk aangegeven dat monitoren geen behandeling is en dat er terughoudend moet worden omgegaan met de vraag om adviezen voor thuis. Veel adviezen hebben te maken met gedragsverandering van de ouders en dat heeft een therapeutisch setting nodig.

\section{Risicofactoren}

Nieuw onderzoek heeft meer duidelijkheid gegeven over de risicofactoren die significant geassocieerd zijn met het persisteren van stotteren (Ambrose e.a., 2015; Kefalianos e.a.,2 017; Ushler e.a., 2017; Walsh e.a., 2018). Ambrose e.a. (2015) vonden in hun meerjarige studie, bij 58 kinderen die stotteren tussen de twee en vier jaar (een op leeftijd en geslacht gematchte controlegroep werd ook gevolgd), dat kinderen die bleven stotteren de volgende kenmerken hadden: een significant lagere score op gestandaardiseerde taaltesten en fonologische testen, een lagere score op articulatorische stabiliteit en door hun ouders vaker beoordeeld met het kenmerk negatieve reactiviteit. Kefalianos e.a. (2017) vonden onder andere dat meisjes die over hogere communicatievaardigheden beschikten op de leeftijd van twee jaar meer kans hebben om te herstellen van stotteren; dit effect werd niet bij jongens gezien. Kinderen die op de leeftijd van zeven jaar hersteld waren van stotteren hadden vaker een sterke taalvaardigheid dan kinderen waarbij het stotteren persisteerde. Ushler e.a. (2017) onderzochten kinderen die waren hersteld van stotteren, kinderen die nog steeds stotterden en kinderen die nooit hadden gestotterd in de leeftijdsgroep tussen de 5;9 en 8;00 jaar. Kinderen die nog steeds stotterden bewogen tijdens het herhaald uitspreken van dezelfde zin- 
nen hun aanzetstuk (het deel van de mond-keelholte boven de stembanden) minder stabiel dan kinderen die waren hersteld van stotteren en de controlegroep. De controlegroep en de groep kinderen die hersteld waren van stotteren verschilden onderling niet significant. Walsh e.a.(2018) vonden dat jongens die stotterden met kleinere en tragere articulatiebewegingen en met minder goed gecoördineerde articulatiebewegingspatronen spraken dan jongens die niet stotterden. Bij meisjes werd dit verschil niet gevonden.

De herziene richtlijn noemt nu, onder meer op basis van boven beschreven studies, de risicofactoren die significant geassocieerd zijn met de kans op blijvend stotteren: tijd sinds het ontstaan van stotteren, leeftijd bij het ontstaan van stotteren, familiegeschiedenis, gender, stottersymptomen (ernst, frequentie, verloop), fonologische ontwikkeling, receptieve en expressieve taal en spraakmotorische vaardigheden. Deze risicofactoren worden als volgt onderverdeeld: er zijn een aantal zwaarwegende risicofactoren (factoren die het meest overtuigend geassocieerd zijn met de kans op blijvend stotteren): het kind is vijf jaar of ouder; er is blijvend stotteren in de familie; het kind is een jongen; het stotteren bestaat al een jaar of langer zonder duidelijke verbetering. Daarnaast zijn er overige risicofactoren die meewegen: het kind heeft zwakke fonologische of spraakmotorische vaardigheden; een zwakke taalontwikkeling of over een langere periode juist een bovengemiddelde taalontwikkeling samen met stotteren; het temperamentskenmerk negatieve reactiviteit; er zijn bijkomende stoornissen. De logopedist dient de risicofactoren te inventariseren en mee te nemen bij de beslissing om te gaan monitoren (en hoe lang), dan wel meteen met behandelen van stotteren te starten (aanbeveling 2).

\section{Screeningslijst Stotteren}

In de vorige richtlijn werd de Screeningslijst Stotteren (SLS) genoemd als middel voor de ouders om te bepalen of nader onderzoek naar stotteren nodig is. Bij de herziene richtlijn is besloten de SLS niet meer in de aanbevelingen op te nemen. Over de validiteit, betrouwbaarheid en normering van de SLS waren ten tijde van de richtlijn in 2014, noch bij de herziening in 2020 onderzoeken bekend. De SLS is inmiddels meer dan twintig jaar oud en is niet meer gebaseerd op de nieuwste inzichten rond stotteren en de risicofactoren zoals boven beschreven. Zo hebben bijvoorbeeld drie van de zes vragen betrekking op de ernst en frequentie van het stotteren. De huidige inzichten geven aan dat de tijd sinds het ontstaan van stotteren en het verloop van het stotteren het risico op persisterend stotteren beter voorspellen dan alleen de ernst van het stotteren. Daarnaast worden een aantal risicofactoren niet meegenomen in de SLS (leeftijd bij ontstaan stotteren, familiegeschiedenis, het geslacht van het kind).

Een nieuwe aanbeveling is dat een gelijktijdige aanwezigheid van taalontwikkelingsstoornissen en stotteren niet mag leiden tot vertraging van de geïndiceerde stottertherapie. Deze aanbeveling wordt ondersteund door Duitse Richtlijn (Neumann e.a., 2016) waar het een consensus aanbeveling is ("Klinische Konsensuspunkt: starker Konsens, 100\% Zustimmung") die op basis van klinische ervaring door de werkgroep herziening richtlijn is overgenomen.

Aanbevelingen voor verder wetenschappelijk onderzoek zijn: onderzoek naar risicofactoren op (blijvend stotteren) inclusief genetische en neurologische factoren, het ontwikke- 
len van een screeningsinstrument voor stotteren, het ontwikkelen van een klinisch onderzoeksinstrument voor spraakmotorische vaardigheid en het onderzoeken van het effect van monitoren van stotteren.

\section{Uitgangsvraag 2: Wat is de diagnostische waarde van tests bij kinderen, adolescenten en volwassenen die stotteren?}

In de richtlijn van 2014 werd de SSI-4 aanbevolen om de ernst van het waarneembare stotteren te meten en werden verschillende onderdelen van de BAB (Behavior Assessment Battery) aanbevolen als meest valide en betrouwbare instrumenten om de aan stotteren gerelateerde emoties, cognities, vermijdingsgedrag en de verschillende aspecten van de kwaliteit van leven te meten. Veel logopedisten gaven aan dat de aanbevelingen bij deze uitgangsvraag duidelijk waren omschreven maar vonden de aanbevelingen niet makkelijk uit te voeren. De SSI-4 is Engelstalig en lastig verkrijgbaar en de BAB werd door velen omschreven als een omslachtig instrument, vooral voor kinderen.

De aanbeveling om de SSI-4 te gebruiken als onderzoeksinstrument voor het bepalen van de ernst van het waarneembare stotteren, is veranderd van een sterke aanbeveling naar een matige sterke aanbeveling. Aanleiding hiervoor is het onderzoek van Davidoff en Scott (2017) waaruit blijkt dat de inter- en intrabeoordelaarsbetrouwbaarheid van de SSI-4 (gemeten in percentage overeenkomst) laag tot middelmatig is als het gaat om de verschillende subscores, maar dat de uiteindelijke ernstscore voldoende overeenkomt. Dit maakt het instrument geschikt om tijdens de diagnostiek een ernstscore te bepalen, maar minder geschikt om vooruitgang in de therapie te meten omdat de sensitiviteit voor de vooruitgang op de verschillende subtesten laag is.

Inmiddels is de Nederlandse vertaling van de OASES (Overall Assessment of Speaker's Experience of Stuttering) gereed en zijn de OASES-S-D (7-12 jaar), de OASES -T-D (12-17 jaar) en de OASES A-D (18 jaar en ouder) gevalideerd op de meeste aspecten en genormeerd voor de Nederlandse bevolking (Koedoot e.a., 2011; Lankman, 2013; Lankman, Yaruss en Franken, 2015). De normering van de BAB is daarentegen aan herziening toe. Om deze reden wordt nu de Nederlandstalige OASES aanbevolen om de impact van het stotteren op de kwaliteit van leven te meten. De BAB en de OASES meten echter niet precies hetzelfde; afname van gewenste onderdelen van de $\mathrm{BAB}$ als aanvulling op de diagnostiek, kan zinvol zijn om meer inzicht te krijgen in de stotterproblematiek.

De KiddyCat (van Ryckegem en Brutten, 2015) is een nieuw instrument dat de reacties op de eigen spraakvaardigheid meet (niet alleen stotteren) bij kinderen tussen de drie en zes jaar. De KiddyCAT laat een duidelijk onderscheid zien tussen kinderen die wel en niet stotteren: ook kinderen met andere spraakproblemen halen hogere scores op de KiddyCAT (Groner, Walden \& Jones, 2016). De KiddyCAT is als zwakke aanbeveling opgenomen omdat de mogelijke nadelige gevolgen van de afname zijn meegewogen. In de discussie hierover komt in de werkgroep herziening richtlijn naar voren dat de afname bij deze jonge doelgroep ook nadelige effecten kan hebben. Het kind zou door de gestelde vragen uit de KiddyCAT meer kunnen gaan nadenken over het eigen spreken waar het voorheen onbevangen was, 
wat negatieve cognities over spreken en stotteren zou kunnen aanwakkeren. De werkgroep vindt het daarom geen onderzoeksinstrument dat bij alle jonge stotterende kinderen zou moeten worden ingezet, maar alleen als daar een aanleiding voor is, bijvoorbeeld wanneer er signalen zijn van een negatieve spreekattitude bij het kind.

Aanbevelingen voor verder wetenschappelijk onderzoek bij deze uitgangsvraag zijn: het ontwikkelen van een screeningsinstrument voor kinderen tot en met zes jaar gebaseerd op de laatste inzichten omtrent risico's voor stotteren; onderzoek naar de betrouwbaarheid van de bestaande diagnostische instrumenten; normeringsonderzoek gebaseerd op een $\mathrm{Ne}$ derlandstalige, representatieve doelgroep, voor bestaande diagnostische instrumenten; de Vlaamstalige versie van de BAB herzien naar een Nederlandstalige versie.

\section{Uitgangsvraag 3: Wat zijn de effecten van stottertherapieën bij kinderen tot en met zes jaar die stotteren (tot en met groep 2 van de basisschool)}

In de richtlijn van 2014 werd aanbevolen om ouders te informeren over de voordelen van behandeling in vergelijking met afwachten en werd aanbevolen om in overleg met ouders een keuze te maken tussen het Lidcombe Programma en behandeling gebaseerd op het Verwachtingen- en Mogelijkhedenmodel. Op dat moment was er een redelijke mate van bewijs voor effect in verminderen van het percentage gestotterde lettergrepen na behandeling met het Lidcombe Programma. Het aantal studies naar het effect van behandeling gebaseerd op het Verwachtingen- en Mogelijkhedenmodel was beperkt en de zekerheid van de effectgrootte gering. Er werd zeer gering bewijs gevonden voor het effect van zowel Speech Motor Training (Daly, Riley \& Riley 1999) als voor het effect van Sociaal Cognitieve gedragstherapie (Boey, 2003).

Het Nederlandse RESTART - studie (Rotterdam Evaluation Study of Stuttering Therapy in pre-school Children, a Randomized Trial) is het grootste onderzoek tot nu toe naar de behandeling van jonge kinderen die stotteren. In 2015 werden de resultaten gepubliceerd (De Sonneville e.a., 2015). In dit onderzoek werd de behandeling volgens Verwachtingenen Mogelijkheden model vergeleken met behandeling volgens het Lidcombe Programma. Omdat er meerdere interpretaties bestaan van de behandeling volgens het Verwachtingenen Mogelijkheden model (Demands and Capacities Model, DCM) is er ten behoeve van het RESTART-onderzoek een handboek geschreven: het RESTART-DCM behandelprotocol (Franken \& Putker, 2012). De uitkomsten van de studie geven aan dat behandelen met RESTART-DCM dezelfde resultaten oplevert als het Lidcombe Programma. Daarnaast maken de auteurs van de studie aannemelijk, onder meer via de vergelijking met de data van Yairi en Ambrose (2005), dat behandelen beter is dan niet behandelen. De aanbeveling om bij kinderen uit groep 1 en 2 van de basisschool een keuze te maken uit één van deze twee behandelmethodes kan op basis van deze evidentie nu met een grotere mate van zekerheid worden geformuleerd dan in de eerste richtlijn. Daarom is dit een sterke aanbeveling geworden. Juist in deze leeftijdsfase, waarin het stotteren nog helemaal kan herstellen met behulp van therapie, is het aanbieden van het juiste behandelprogramma cruciaal.

In 2018 werd het behandelprogramma Mini-KIDS gepubliceerd; naar dit behandelpro- 
gramma is nog geen effectonderzoek gedaan en is daarom geen onderdeel van de aanbevelingen. Mini-KIDS is een directie therapie waarbij het durven en kunnen stotteren centraal staat.

Aanbevelingen voor verder wetenschappelijk onderzoek zijn: het onderzoek naar de effecten op de lange termijn voor Lidcombe Programma en RESTART-DCM en overige behandelingen; welke behandeling is het meeste geschikt voor welk kind en voor welke manier van stotteren; onderzoek naar eventuele ongewenste effecten van RESTART-DCM.

\section{Uitgangsvraag 4: Wat zijn de effecten van stottertherapieën bij kinderen van zes tot en met dertien jaar die stotteren? (groep drie tot en met acht van de basisschool)}

In de richtlijn van 2014 werd geconcludeerd dat het aantal studies naar het effect van de behandeling van kinderen die stotteren in de leeftijd tussen de 6 en 13 jaar beperkt is en de kwaliteit voor het bewijs van het effect overwegend laag. Er werd een algemene aanbeveling geformuleerd waarbij geadviseerd werd dat het behandelplan bij voorkeur alle ICFelementen bevat en dat de behandeling zich in overleg met het kind en de ouders zich richt op die gedragingen, emoties en cognities die uit het onderzoek naar voren zijn gekomen. Uit de enquête kwam naar voren dat aanbevelingen duidelijk geformuleerd waren.

Voor de herziening is gebruik gemaakt van de systematische reviews van Baxter e.a. (2015 en 2016). In deze reviews komt naar voren dat er geen aanwijzingen zijn dat één bepaalde therapie voor stotteren bij kinderen van 6 tot 13 jaar (groep 3 tot en met groep 8 van de basisschool) de beste is. Om deze reden is maatwerk vereist. Het behandelplan wordt opgesteld met het kind dat stottert en zijn/haar ouders.

Diverse handboeken (o.a. Bezemer \& Bouwen, 2018; Guitar, 2018; Manning, 2010) beschrijven dat er aandacht dient te zijn voor cognitieve, emotionele en sociale factoren naast spraakmotorische training. Caughter en Dunsmuir (2016) vonden in hun multiple case studie door middel van thematische analyse van kwalitatieve data (semi-gestructureerde interviews) dat cognitieve en emotionele veranderingen de belangrijkste resultaten waren van de behandeling van kinderen tussen de 10-14 jaar. Uit kwantitatieve data bleek voor alle kinderen een vermindering van de impact van het stotteren ( OASES-S). Als er met deze veranderingen ook ervaring wordt opgedaan in het dagelijks leven van het kind, bleven de resultaten na 12 maanden nog in stand. De omgeving van de het kind is nodig om deze ervaringen te kunnen faciliteren.

Op basis van deze twee recente publicaties konden de aanbevelingen bij uitgangsvraag 4 specifieker en sterker geformuleerd worden. Een voorbeeld hiervan is aanbeveling 12 waarin wordt omschreven de ouders én de directe omgeving (grootouders, leerkrachten) van kinderen van zes tot en met 13 jaar actief te betrekken bij de therapie en de overdracht van de geleerde vaardigheden naar het dagelijks leven. Daarnaast worden vier aandachtspunten voor behandeling genoemd: emotionele, cognitieve, sociale en spraak-motorische aspecten van stotteren; in de vorige richtlijn werd deze aspecten minder specifiek benoemd.

De aanbeveling om aandacht te hebben voor pesten bij kinderen is bij uitgangsvraag 4 
opgenomen. Er is inmiddels een vertaling van de Teasing en Bullying Questionnaire-CSrevised (Langevin, 2009 en 2013) beschikbaar in de bijlage van de richtlijn, die gebruikt kan worden bij het bespreken van pesten bij stotteren.

Aanbevelingen voor verder wetenschappelijk onderzoek bij kinderen tussen de zes en dertien jaar zijn: nader onderzoek naar de effectiviteit van stottertherapie; onderzoek naar het gebruik van cognitieve gedragstherapie in de behandeling van kinderen die stotteren; nader onderzoek naar de betrokkenheid van de omgeving en de invloed die dit heeft op de therapie-uitkomsten.

\section{Uitgangsvraag 5: Wat zijn de effecten van stottertherapieën bij adolescen- ten en volwassenen die stotteren?}

Voor de behandeling van adolescenten en volwassenen werden voor de richtlijn van 2014 onderzoeken van diverse behandelmethodes bestudeerd en was de zekerheid van de effectgrootte gering voor alle relevante uitkomstmaten. De vier aanbevelingen richtten zich op de ICF-elementen, op de behandeling van verbaal-motorische aspecten en/of psychosociale effecten van het stotteren door cognitieve gedragstherapie, groepstherapie en transfer. Het gebruik van op AAF (Altered Auditory Feedback) gebaseerde apparaten en farmacotherapie bij stotteren werd afgeraden. Uit de enquête onder de gebruikers van de richtlijn kwam naar voren dat de aanbevelingen duidelijk geformuleerd waren, bij de uitvoering wordt door sommigen het gebrek aan ervaring met cognitieve gedragstherapie genoemd. Bij de uitvoering van groepstherapie werd het tarief voor groepstherapie in de eigen praktijk door sommigen als laag ervaren en was de verwijzing naar intensieve groepstherapie regelmatig niet succesvol onder meer vanwege praktische bezwaren omtrent data en locatie.

Ook voor adolescenten en volwassenen zijn in de systematische reviews van Baxter e.a. (2015 en 2016) geen aanwijzingen gevonden dat één bepaalde therapie beter werkt dan een andere. Connery e.a. (2019) beschrijven in hun systematisch review van kwalitatieve studies de ervaringen van volwassenen die stotteren en de betekenis hiervan in hun leven. Ook hier komen sterk de cognitieve, emotionele en sociale aspecten van stotteren naar voren. Dit impliceert dat clinici zich bewust moeten zijn van de verstrekkende gevolgen van stotteren. Met alleen aandacht voor de uiterlijke kenmerken van stotteren wordt geen recht gedaan aan de geïnternaliseerde gedachten en gevoelens over stotteren. Op basis van deze twee recente studies zijn de aanbevelingen nu specifieker en sterker geformuleerd en worden, net als bij kinderen van 6 tot 13 jaar, vier behandelcomponenten genoemd.

Baxter e.a. (2015 en 2016) benadrukken tevens het belang van interactiemogelijkheden met andere mensen die stotteren. Voor adolescenten en volwassenen is er een aparte aanbeveling voor groepstherapie opgenomen.

Aanbevelingen voor verder wetenschappelijk onderzoek bij adolescenten en volwassenen zijn: nader onderzoek naar de effectiviteit van stottertherapieën onder meer ook om inzicht te krijgen in welk onderdeel van de therapie het meeste effect heeft; nader onderzoek naar de toepassing van cognitieve gedragstherapie; onderzoek naar de effecten van groepstherapie of lotgenotencontact. 


\section{Uitgangsvraag 6: Hoe dient adequate nazorg te worden georganiseerd bij kinderen, adolescenten en volwassenen die stotteren?}

Voor de richtlijn van 2014 werden de uitgangspunten van goede nazorg geïnventariseerd en werd een individuele programmatische aanpak gedurende twee jaar aanbevolen.

Uit de enquête naar het gebruik van de richtlijn van 2014 bleek dat de helft van de respondenten de aanbeveling om programmatische nazorg aan te bieden over een periode van twee jaar, niet haalbaar vond. De termijn van twee jaar bleek het grootste struikelblok, daarnaast was het verschil tussen stabilisatie/consolidatiefase en nazorg niet duidelijk. In de herziene richtlijn is omschreven dat nazorg de fase van stabilisatie is die begint zodra het vooraf vastgestelde realistische hoofddoel is bereikt. In navolging van wat gebruikelijk is bij de afronding van een psychologische behandeling heeft de werkgroep de term "terugvalpreventieplan" overgenomen (Keijsers e.a., 2017). In een terugvalpreventieplan beschrijft de persoon die stottert (of de ouders van een kind dat stottert) hoe met toenemende zelfstandigheid het bereikte resultaat kan worden vasthouden en om hoe kan worden omgegaan met eventuele terugval. De persoon die stottert (of de ouders van het kind dat stottert) bepaalt hierbij zelf de duur van de nazorg en beschrijft de indicaties om contact op te nemen met de logopedist. In de bijlage van de richtlijn worden voorbeelden gegeven van een terugvalpreventieplan bij de behandeling van stotteren.

Wetenschappelijk onderzoek naar de factoren die een rol spelen bij de terugval na behandeling van stotteren en factoren die terugval verminderen, wordt aanbevolen.

\section{Uitgangsvraag 7: Wanneer en met welke reden dienen kinderen, adoles- centen en volwassenen die stotteren te worden doorverwezen?}

De richtlijn van 2014 werden zes aanbevelingen omschreven met indicaties om door te verwijzen. Uit de enquête bleek dat deze aanbevelingen voldoende omschreven zijn en redelijk uitvoerbaar zijn. Bij de herziening zijn de aanbevelingen korter omschreven en enkele nuances zijn veranderd.

De consensus-aanbeveling om eens per drie maanden te evalueren is veranderd van een matig sterke aanbeveling naar een sterke aanbeveling mede gebaseerd op de inhoud van de Duitse richtlijn. In de Duitse richtlijn wordt ervan uitgegaan dat na tien tot vijftien sessies verandering zichtbaar moet zijn. Bij deze aanbeveling is duidelijker beschreven dat bij onvoldoende vooruitgang niet alleen de logopedist maar ook de logopedist-stottertherapeut een (andere) logopedist-stottertherapeut dient te consulteren.

Bij de behandeling van kinderen tot en met zes jaar volgens het Lidcombe Programma en behandeling volgens RESTART-DCM is er evidentie dat gemiddeld na elf tot twaalf behandelsessies een significant verlaging van de stotterernst optreedt (De Sonneville-Koedoot e.a., 2015; Millard, Nicholas, \& Cook, 2008, Yaruss, Coleman, \& Hammer, 2006).

Ook is opgenomen dat er verwezen kan worden naar een psycholoog bij het vermoeden van problemen van psychologische aard. Daarnaast worden in de herziene richtlijn de mogelijkheden om een psycholoog te betrekken bij sommige aspecten van de stotterbehan- 
deling beschreven.

Aanbevelingen voor verder wetenschappelijk onderzoek zijn: onderzoek naar de mogelijkheid en /of effectiviteit van samenwerken en/of doorverwijzen naar andere disciplines zoals een psycholoog of een orthopedagoog of een maatschappelijk werker.

\section{Implementatie}

Het schrijven van een richtlijn maakt niet automatisch dat de aanbevelingen in de beroepspraktijk worden uitgevoerd. Er is aandacht nodig voor de verspreiding en toegankelijkheid van de richtlijn, voor educatie en training en voor implementatie in het werkproces (organisatorische en administratieve elementen). De motivatie en de attitude van logopedisten ten aanzien van de richtlijn wegen mee bij het succesvol implementeren van een richtlijn (Fischer et al, 2016). Een speciale werkgroep implementatie richtlijn stotteren ontwikkelt activiteiten om de toepassing van de huidige richtlijn in de praktijk te bevorderen. Inmiddels is de richtlijn gepubliceerd in een toegankelijke, interactieve opmaak en is er een webinar beschikbaar op de website van de NVLF. Een e-learning module over monitoren bij jonge stotterende kinderen is in voorbereiding. Het elektronisch patiënten dossier (epd) wordt aangepast zodat de logopedist bij de invoer van de onderzoeks- en behandelgegevens moet aangeven of de richtlijnaanbevelingen zijn opgevolgd bij de betreffende cliënt. Ook dit artikel in een themanummer over stotteren is van nut voor de implementatie omdat het aandacht voor de actuele richtlijn genereert. Net als voor de oude versie van de richtlijn stotteren is er een speciale, makkelijk leesbare versie ontwikkeld voor de cliëntengroep, met steun van Demosthenes (Tonnis \& Van Ormondt, 2021).

\section{Implementatie}

Het is de bedoeling dat met het herzien van de richtlijn stotteren uit 2014 een bijdrage is geleverd aan de kwaliteit van zorg voor personen die stotteren in Nederland.

Er zijn helaas nog veel kennishiaten op het betreffende onderzoeksgebied. Zo is er beperkte kennis over de effectiviteit van stottertherapieën en is er gering onderzoek beschikbaar over therapieën bij schoolkinderen. Veel van de effectonderzoeken richten zich op de uitkomstmaat stotterfrequentie en stotterernst. Daarmee wordt geen recht gedaan aan overige cruciale uitkomstmaten die te maken hebben met de kwaliteit van leven en communicatieve participatie. Maar ook op andere punten valt nog veel kennis te vergaren, zoals blijkt uit de door de werkgroep geformuleerde aanbevelingen voor verder onderzoek.

Om up-to-date te blijven zal over vijf jaar opnieuw worden bekeken of herziening van de richtlijn uit 2020 relevant is. 


\section{Literatuur}

AGREE Next Steps Consortium. Appraisal of Guidelines for Research \& Evaluation (AGREE) II Instrument. www.agreetrust.org

Ambrose, N. G., Yairi, E., Loucksa, T. M., Seery C. H., \& Throneburg, R. (2015) Relation of motor, linguistic and temperament factors in epidemiologic subtypes of persistent and recovered stuttering: Initial findings. Journal of Fluency Disorders, 45, 12-16.

Baxter, S., Johnson, M., Blank, L., Cantrell, A., Brumfitt, S., Enderby, P., \& Goyder, E. (2015). The state of the art in non-pharmacological interventions for developmental stuttering. Part 1: a systematic review of effectiveness. International Journal of Language \& Communication Disorders, 50(5), 676-718.

Baxter, S., Johnson, M., Blank, L., Cantrell, A., Brumfitt, S., Enderby, P., Goyder, E. (2016). Non-pharmacological treatments for stuttering in children and adults: a systematic review and evaluation of clinical effectiveness, and exploration of barriers to successful outcomes. Health Technology Assessment, 20(2), 1-302, doi.org/10.3310/hta20020

Bezemer, M., \& Bouwen, J. (2018). Stotteren: Van Theorie naar therapie. Coutinho. Boey, R. (2003). Stotteren en stottertherapie bij heel jonge kinderen. Sociaal-cognitieve gedragstherapie. Acco.

Caughter, S., \& Dunsmuir, S. (2016). An exploration of the mechanisms of change following an integrated group intervention for stuttering, as perceived by school-aged children who stutter (CWS). Journal of Fluency Disorders, 51, 8-23.

Davidow, J. H., \& Scott, K. A. (2017). Intrajudge and Interjudge Reliability of the Stuttering Severity InstrumentFourth Edition. American Journal of Speech-Language Pathology, $26,1105-1119$.

Daly, A.D., Riley, J., \& Riley, G. (1999). Speech Motor Exercises: A Program for People Who Stutter, Pro-Ed Publishing Company.

De Sonneville-Koedoot C., Stolk, E., Rietveld T., \& Franken M.C. (2015). Direct versus Indirect Treatment for Preschool Children who Stutter: The RESTART Randomized Trial. PLoS One, 7, doi:10.1371/journal.pone.0133758

Franken, M. C., \& Putker, D. (2012). Restart-DCM Werkwijze. Behandelprotocol ontwikkeld in het kader van het ZonMW project Cost-effectiveness of the Demands and Capacities Model based treatment compared to the Lidcombe programme of early stuttering intervention: Randomised trial. www.restartdcm.nl

Fischer, F., Lange, K., Klose, K., Greiner, W., \& Kraemer, A. (2016). Barriers and Strategies in Guideline Implementation: A Scoping Review, Healthcare, 4, 36. doi:10.3390/healthcare4030036

Groner, S., Walden, T., \& Jones, R. (2016). Factors Associated With Negative Attitudes Toward Speaking in Preschool-Age Children Who Do and Do Not Stutter, Contemporary Issues in Communication Science and Disorders, 43, 255-267, https://pubs.asha.org 83.163.239.114

Guitar,B (2018). Stuttering: an integrated approach to its nature an treatment. 5th edition. Lippincott Williams \& Wilkins.

Kefalianos, E., Onslow, M., Packman, A., Vogel, A., Pezic, A., Mensah, F., Conway, L., Bavin, 
E., Block, S., \& Reilly, S. (2017). The History of Stuttering by 7 Years of Age: Follow-Up of a Prospective Community Cohort. J Speech Lang Hear Res., 60(10), 2828-2839.

Keijsers, G. P. J., Van Minnen, A., Verbraak, M. J. P. M., Hoogduin, C. A. L., \& Emmelkamp, P. M. G. (2017). Protocollaire behandelingen voor volwassenen met psychische klachten. Boom.

Koedoot, C., Bouwmans, C., Franken, M., \& Stolk, E. (2011). Quality of life in adults who stutter. Journal of Communication Disorders, 44, 429-443.

Langevin, M. (2009). The Peer Attitudes Toward Children who Stutter scale: Reliability, known groups validity, and negativity of elementary school-age children's attitudes. Journal of Fluency Disorders, 34, 72-86.

Lankman, R. (2013). Validatie en evaluatie van de Nederlandse vertaling van de Overall Assessment of the Speaker's Experience of Stuttering for teenagers and school-age children' (OASES-T-NL \& OASES-S-NL). Scriptie wetenschappelijke onderzoeksstage geneeskunde VU, UMCR.

Lankman, R., Scott Yaruss, J., \& Franken, M. (2015). Validation and evaluation of the Dutch translation of the Overall Assessment of the Speaker's Experience of Stuttering for Schoolage children (OASES-S-D). Journal of Fluency Disorders, 45, 27-37.

Manning, W.H. (2010). Clinical Decision Making in fluency disorders. Delmar: Cengage Learning.

Millard, S. K., Nicholas, A., \& Cook, F. M. (2008). Is Parent-Child Interaction Therapy Effective in Reducing Stuttering? Journal of Speech, Language, and Hearing Research, 51, 636-650.

Neumann, K., Euler, H.A., Bosshardt H. G., Cook, S., Sandrieser, P., Schneider, P., Sommer, M., \& Thum, G. (2016). Pathogenese, Diagnostik und Behandlung von Redeflussstörungen. Evidenz- und konsensbasierte S3-Leitlinie.

Verkregen van http://www.awmf.org/leitlinien/detail/ll/049-013.html

NVLF (2020). Richtlijn stotteren bij kinderen, adolescenten en volwassenen. https://www.nvlf.nl/kennis/inhoudelijke-richtlijnen/

Oonk, L.C., \& Pertijs, M.A.J. (2015). De evidence-based richtlijn stotteren bij kinderen, adolescenten en volwassenen. Nederlands Tijdschrift voor Logopedie, 87, 22-26.

Pertijs, M.A.J., Oonk, L.C., Beer, de J.J.A., Bunschoten, E.M., Bast, E.J.E.G., Ormondt, van J., Rosenbrand, C.J.G.M., Bezemer, M., Wijngaarden, van L.J., Kalter, E.J., Veenendaal, van H. (2014). Evidence-based Richtlijn Stotteren bij kinderen, adolescenten en volwassenen. Nederlandse Vereniging voor Logopedie en Foniatrie, Woerden.

Tonnis, M., \& Van Ormondt, J. (2021- 1 oktober). Patiëntenversie Richtlijn Stotteren 2020. Demosthenes. Verkregen https://www.stotteren.nl/ouders.html

Ushler, E., Smith, A., \& Weber, C. (2017). A Lag in Speech Motor Coordination During Sentence Production Is Associated With Stuttering Persistence in Young Children. Journal of Speech, Language, and Hearing Research, 60, 51-61.

Vanryckeghem, M., \& Brutten, G. (2015). KiddyCAT: Communication Attitude Test voor stotterende kleuters. Destelbergen, Belgium: Sig vzw.

Waelkens, V. (2018). MINI-KIDS stottertherapie bij jonge stotterende kinderen (2-6 jaar). Acco. 
Walsh, B., Usler, E., Bostian, Mohan, R., Gerwin, K.L., Brown, B., Weber, C. \& Smith, A. (2018). What Are Predictors for Persistence in Childhood Stuttering? Semin Speech Lang, 39(4), 299-312. doi: 10.1055/s-0038-1667159.

Yairi, E., \& Ambrose, N. G. (2005). Early childhood stuttering. Pro-Ed.

Yairi, E., \& Seery, C.H. (2015). Stuttering: Foundations and Clinical Applications. Harlow, England: Pearson.

Yaruss, J. S., Coleman, C., \& Hammer, D. (2006). Treating Preschool Children Who Stutter: Description and Preliminary Evaluation of a Family-Focused Treatment Approach. Language, Speech, and Hearing Services in Schools, 118-136. 


\section{Appendix}

Tabel 3: Overzicht van 24 aanbevelingen in de herziene richtlijn stotteren 2020.

1. Sterk

2. Sterk

3. Sterk

4. Matig sterk

5. Sterk

6. Matig sterk
Als bij een kind jonger dan 4;6 jaar, het stotteren minder dan een half jaar voor de intake bij de logopedist is begonnen, dient deze mogelijk natuurlijk herstel te monitoren. Het monitoren gaat over in een reguliere behandeling als de stotterernst negen tot twaalf maanden na het ontstaan van stotteren niet duidelijk* is afgenomen ten opzichte van de stotterernst kort na het ontstaan. Is het stotteren wel duidelijk afgenomen, dan kan het monitoren worden voortgezet zolang het herstel zich voortzet. Als het herstel niet meer doorzet wordt behandeling gestart.

De logopedist dient bij kinderen tot en met zes jaar (tot en met groep twee van de basisschool) de risicofactoren op blijvend stotteren te inventariseren** en mee te nemen bij de beslissing om te gaan monitoren (en hoe lang), dan wel meteen met behandelen van stotteren te starten. De risicofactoren die in deze overweging zwaar wegen zijn: het kind is vijf jaar of ouder; er is blijvend stotteren in de familie; het kind is een jongen; het stotteren bestaat al een jaar of langer zonder duidelijke verbetering. Overige risicofactoren die meewegen zijn: het kind heeft zwakke fonologische of spraakmotorische vaardigheden; een zwakke taalontwikkeling; over een langere periode een bovengemiddelde taalontwikkeling samen met stotteren; het temperamentskenmerk negatieve reactiviteit; er zijn bijkomende stoornissen.

De logopedist dient behandeling niet (langer) uit te stellen als (1) het kind onder het stotteren lijdt of weerzin krijgt om te communiceren (2) ouders het stotteren ook na het advies- of voorlichtingsgesprek nog steeds erg belastend vinden of onvoldoende vertrouwen hebben in een beleid van monitoren.

De logopedist wordt aanbevolen bij kinderen vanaf groep drie van de basisschool, adolescenten of volwassenen met een hulpvraag op gebied van stotteren, op grond van een inventarisatie van ICF-elementen, samen met de hulpvrager te bepalen welke behandeldoelen geïndiceerd zijn voor de persoon die stottert.

Gelijktijdige aanwezigheid van stotteren en een taalontwikkelingsstoornis mag niet leiden tot vertraging van een geïndiceerde stottertherapie. In het geval van andere comorbiditeiten bij stotteren zoals een angststoornis of een depressie, dient geprioriteerd te worden in welke volgorde de diverse therapieën gegeven moeten worden.

De logopedist wordt geadviseerd de SSI-4 te gebruiken als onderzoeksinstrument voor het bepalen van de ernst van het waarneembare stotteren. 
7a. Sterk

7b. Matig sterk

7c. Zwak

8. Sterk

9. Sterk

10. Sterk

11. Matig sterk

12. Sterk

13. Sterk

14. Sterk

15. Sterk

16. Matig sterk
De logopedist dient onderzoek te doen naar de aan het stotteren gerelateerde emoties, cognities, vermijdingsreacties en verschillende aspecten van de kwaliteit van leven.

Voor volwassenen, adolescenten en kinderen vanaf zeven jaar wordt de OASES A-D (volwassenen), T-D (12-17 jaar) of S-D (7-12 jaar) aanbevolen. Het gebruik van (onderdelen van) de Behavior Assessment Battery (BAB) kan zinvol zijn om de stotterproblematiek verder in kaart te brengen. Voor kinderen tot en met zes jaar kan de logopedist de KiddyCAT overwegen als instrument om de spreekattitude te onderzoeken.

De logopedist dient bij de behandeling van kinderen die stotteren tot en met zes jaar in overleg met de ouders een keuze te maken tussen het Lidcombe Programma en de RESTART-DCM behandeling.

De logopedist dient het behandelplan voor stotteren bij kinderen van zes tot dertien jaar (groep drie tot en met acht) in samenspraak met het kind en zijn/haar ouders te formuleren en te baseren op de individuele behoeften en mogelijkheden van het kind dat stottert.

De logopedist dient in de therapie van stotteren bij kinderen van zes tot dertien jaar (groep drie tot en met acht) aandacht te hebben voor de emotionele, cognitieve, sociale en spraakmotorische aspecten van het stotteren.

De logopedist wordt geadviseerd na te vragen of er bij stotterende kinderen en jongeren sprake is van pesten en in overeenkomst met het antwoord te handelen.

De logopedist dient de ouders van kinderen van zes tot dertien jaar (groep drie tot en met acht) actief deel te laten nemen aan de therapie en met de ouders te bespreken hoe zij hun kind kunnen begeleiden bij de transfer van de geleerde vaardigheden naar situaties uit het dagelijks leven. Daarnaast wordt geadviseerd om de omgeving (grootouders, leerkrachten, ed.) actief te betrekken bij de therapie, om de transfer van de geleerde vaardigheden naar het dagelijks leven te vergemakkelijken.

De logopedist dient het behandelplan voor adolescenten en volwassenen die stotteren in samenspraak te formuleren en te baseren op de individuele behoeften en mogelijkheden van de persoon die stottert.

De logopedist dient in de stottertherapie bij adolescenten en volwassenen aandacht te hebben voor emotionele, cognitieve, sociale en spraakmotorische aspecten van het stotteren, waarbij gewerkt wordt met dagelijkse situaties van de persoon die stottert.

De logopedist dient in de therapie aandacht te besteden aan het bevorderen van transfer van de geleerde vaardigheden naar situaties in het dagelijks leven van de persoon die stottert.

De logopedist streeft ernaar om de mogelijkheden tot groepstherapie, als aanvulling op de reguliere individuele therapie, samen met de adolescent of volwassene die stottert te verkennen. 
17. Sterk

18. Sterk

19. Matig sterk

20. Sterk

21. Sterk

22. Sterk

De logopedist dient in de afrondende fase van de behandeling samen met de persoon die stottert, het kind dat stottert en/of de ouders van het kind dat stottert een terugvalpreventieplan op te stellen en de uitvoering van het plan te begeleiden.

De logopedist dient de aanbevelingen uit deze richtlijn voor diagnostisch en therapeutisch handelen te kunnen uitvoeren. Indien de logopedist zich daartoe onvoldoende in staat acht, verwijst de logopedist door naar een logopedist met meer expertise op het gebied van stotteren.

De logopedist wordt geadviseerd tijdens de diagnostische fase informatie te geven aan (ouders van) de persoon die stottert over de verschillen in opleiding en expertise van logopedisten, zodat men in staat is een geïnformeerde keuze te maken ten aanzien van de behandeling.

Als er bij de therapie bij stotterende kinderen tot en met zes jaar (tot en met groep twee van de basisschool) na drie maanden van actieve behandeling met frequente sessies geen significante verbetering in het stotteren optreedt, dient een logopedist met specialistische expertise op het gebied van stotteren te worden geconsulteerd.

De logopedist dient ten minste eens per drie maanden te evalueren. Als tijdens de evaluaties van het therapieproces blijkt dat de smartbehandeldoelen onvoldoende zijn gerealiseerd volgens (de ouders van) de persoon die stottert of de logopedist, dan dient een (andere) logopedist ${ }^{3}$ met specialistische expertise op het gebied van stotteren geconsulteerd te worden. De logopedist kan ook de wenselijkheid van verwijzing naar een andere behandelaar ${ }^{4}$ bespreken met de persoon die stottert en/of diens ouders.

Bij het vermoeden van problemen van psychologische aard, zoals sociale angst, negatief zelfbeeld, paniekaanvallen of depressie, bij de persoon die stottert dient de logopedist te overleggen met (ouders van) de persoon die stottert over een mogelijke verwijzing naar bijvoorbeeld een psycholoog, psychiater of orthopedagoog. De logopedist kan de vermoedens eerst objectiveren middels een screeningslijst.

Noot: De richtlijn uit 2014 bevatte 25 aanbevelingen. de Richtlijnen 2020 bevatten 24 aanbevelingen, inclusief $7 \mathrm{a}, 7 \mathrm{~b}$ en $7 \mathrm{c}$.

\footnotetext{
${ }^{3}$ Ook een logopedist met specialistische kennis op het gebied van stotteren dient een andere logopedist met specialistische kennis te raadplegen bij het onvoldoende behalen van smart-behandeldoelen.

${ }^{4}$ Een andere behandelaar zoals een psycholoog, orthopedagoog of maatschappelijk werker.
} 